\title{
Effect of breastfeeding on bone mass from childhood to adulthood: a systematic review of the literature
}

\author{
Ludmila Correa Muniz*, Ana Maria Baptista Menezes, Romina Buffarini, Fernando Cesar Wehrmeister \\ and Maria Cecília Formoso Assunção
}

\begin{abstract}
Background: Conflicting results exist about the short-and long-term effects of breastfeeding on bone mineral content (BMC) and bone mineral density (BMD). We conducted a systematic review to assess the relationship between method of infant feeding and bone mass in children, adolescents and adults.

Methods: The literature review was concluded in September 2014 in MEDLINE, Web of Science and LILACS databases and articles published between 1998 and 2013 were included. Studies using dual-energy X-ray absorptiometry (DXA) instrument to assess the bone mineral content and/or bone mineral density (BMD) of total body, lumbar spine, femoral neck, or at least one of these sites were included in the review.

Results: From the 648 references identified, eleven were selected, ten of which had a longitudinal design. All studies were conducted in high-income countries, six evaluated the outcome in children, four in adolescents and one in young adults ( $<35$ years). Of the studies that assessed the outcome in childhood, two found a positive association and the others showed a negative effect of being breastfed on bone mass. In adolescence, three studies showed a positive association between being breastfed and bone outcomes. Among adults, a negative effect of being breastfed exclusively for a longer period of time on bone mass was observed only in men. In women, there was no effect of being breastfed on bone mass.
\end{abstract}

Conclusions: There is no consensus on the effects of method of infant feeding on an individual's bone mass at different ages.

Keywords: Absorptiometry, Breast feeding, Bone density, Review

\section{Background}

Development of the skeleton and subsequent bone health is influenced by a complex interaction of genetic, demographic, socioeconomic, hormonal and environmental factors [1]. Based on evidence from life course studies, early factors inherent to the intrauterine period and early years of life can also influence bone outcomes, as suggested by Barker's hypothesis [2-4].

To the best of our knowledge, no evidence exists concerning the relationship between intrauterine nutrition and bone mass. However, the association between nutritional exposure during the first year of life and bone

\footnotetext{
* Correspondence: ludmuniz@yahoo.com.br

Postgraduate Program in Epidemiology, Federal University of Pelotas, Pelotas,
} Brazil

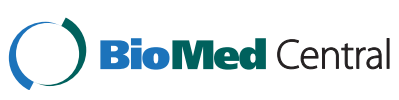

(C) 2015 Muniz et al. Open Access This article is distributed under the terms of the Creative Commons Attribution 4.0 International License (http://creativecommons.org/licenses/by/4.0/), which permits unrestricted use, distribution, and reproduction in any medium, provided you give appropriate credit to the original author(s) and the source, provide a link to the Creative Commons license, and indicate if changes were made. The Creative Commons Public Domain Dedication waiver (http://creativecommons.org/publicdomain/zero/1.0/) applies to the data made available in this article, unless otherwise stated.

mass at different ages has been assessed in some studies. With regard to method of infant feeding, results of investigations into its short and long-term effects on bone mineral content and/or density are conflicting. Some authors have shown a positive effect of being breastfed on bone mass in childhood and adolescence [5-9]. However, other studies have found no association or a negative effect of being breastfed on bone mass outcomes [10-15].

Breastfeeding is universally recognized as the ideal way of feeding infants. The practice is widely recommended by health bodies, given its benefits in terms of nutritional status, cognitive and physical development, reducing mortality for the infant, and the rates of some chronic conditions in adult life [16]. In addition, knowledge on the early 
modifiable factors influencing bone mass acquisition could allow prevention of osteoporosis and osteoporotic fractures, problems that represent a major social and financial burden for society [17].

Therefore, the objective of the present review was to investigate the relationship between the method of infant feeding and bone mass during childhood, adolescence and/or adult life. In view of the heterogeneity in approaches for assessing the exposure of interest, it was decided to perform a systematic review of the literature as opposed to a meta-analysis.

\section{Methods}

\section{Search strategy}

The literature search, concluded in September 2014, was carried out on the MEDLINE/PubMed, Web of Science (WoS) and Literatura Latino-Americana e do Caribe em Ciências da Saúde (LILACS) databases using free terms for the searching of references. Two groups of key words were created using the connectors "OR" and "AND", within each group and between the groups, respectively. The terms used for the definition of bone mineral content or density were: "bone mass", "bone density", "bone mineral density", "bone mineral content", "bone area", "bone health" and "osteoporosis" (first group). For the exposure of interest, the second group included the terms "breast feeding", "breast feeding, exclusive", "breastfeeding", "breastfeeding, exclusive" and "milk, human". There were no constraints on publication date or language.

\section{Inclusion/exclusion criteria of articles}

The criteria for inclusion of articles were: being original; having evaluated the relationship between being breastfed and bone mineral content (BMC) and/or bone mineral density (BMD) during childhood, adolescence or in adults; and having used the Dual-energy X-ray Absorptiometry method (DXA) for assessing BMC and/or BMD of the whole body, lumbar spine, neck of the femur or in at least one of these sites.

Studies involving animals or specific population groups such as volunteers, twins and individuals who were sick, premature, with low birth weight or small for gestational age were considered ineligible.

\section{Selection and quality assessment of articles}

After the search process, the references were imported into the software EndNote $\times 3$ (Thompson Reuters, USA) and duplicate references excluded. All the stages of article selection were performed independently by two authors (LCM and RB) and, in cases lacking consensus, a third author (MCA) was consulted. Initially, the authors performed a reading of the titles, excluding those which did not address the association of interest or fulfil the previously defined inclusion criteria. Subsequently, abstracts were read followed by full reading of those articles deemed relevant. After this stage, the lists of references of the selected articles were checked, yielding no further studies.

An adapted version of the scale proposed by Downs and Black was used for the assessment of the methodological quality of the selected articles [18]. Adaptation was required because some items in the original scale did not apply to the cross-sectional, observational or cohort studies. Thus, out of the original 27 items, a total of 17 were assessed as shown in Table 1.

Each item was scored as 0 (no) or 1 (yes), with the exception of item four, which was assigned scores of 0 (no), 1 (partially) or 2 (yes). Final score ranged from zero to 18 points. Based on the score attained, the articles assessed were classified as: low internal validity (0-5 points), intermediate internal validity (6-11 points) and high internal validity (12-18 points). The articles were assessed for these criteria independently by two authors (LCM and RB) and, in cases without consensus, a third author (MCA) was consulted.

\section{Results}

A total of 648 references were retrieved, comprising 380 on Pubmed, 251 on WoS and 17 on the LILACS databases. After exclusion of 100 to duplicate references, 548 were selected for reading of the titles. Upon conclusion of the selection process, 11 articles were included in the review. All phases of the reference selection process, as well as the number of studies included and excluded at each stage, can be seen in the flow chart depicted in Fig. 1.

The main characteristics of the 11 articles included in this review are given in Table 2. All of the studies were published in English between 1998 [13] and 2013 [5, 8, $11]$, comprising nine cohort studies [5-10, 12, 14, 15], one randomised trial [11] and one cross-sectional studies [13]. Sample sizes ranged from 35 [13] to 599 [12] subjects. Six of the studies assessed outcome in children ( $<10$ years) $[5,7,10,12,13,15]$, four tracked adolescents (10-19 years) [1, 6, 8, 9] and one involved adults ( $<35$ years) [14]. All the studies were carried out in highincome countries. Median score obtained on the Downs \& Black assessment was 15 points (minimum 10 and maximum 16 points). Based on the results of this assessment, nine out of the eleven articles were classified as having high internal validity.

The method of infant feeding variable was assessed differently by the studies. Three studies $[11,13,15]$ assessed the effect of being exclusively breastfed (EBF) compared to being fed infant formula. One study assessed EBF up to the third month of life [11], one from birth to the fourth month [15] and the other up to the 
Table 1 Criteria for evaluation adapted from Downs and Black [18]

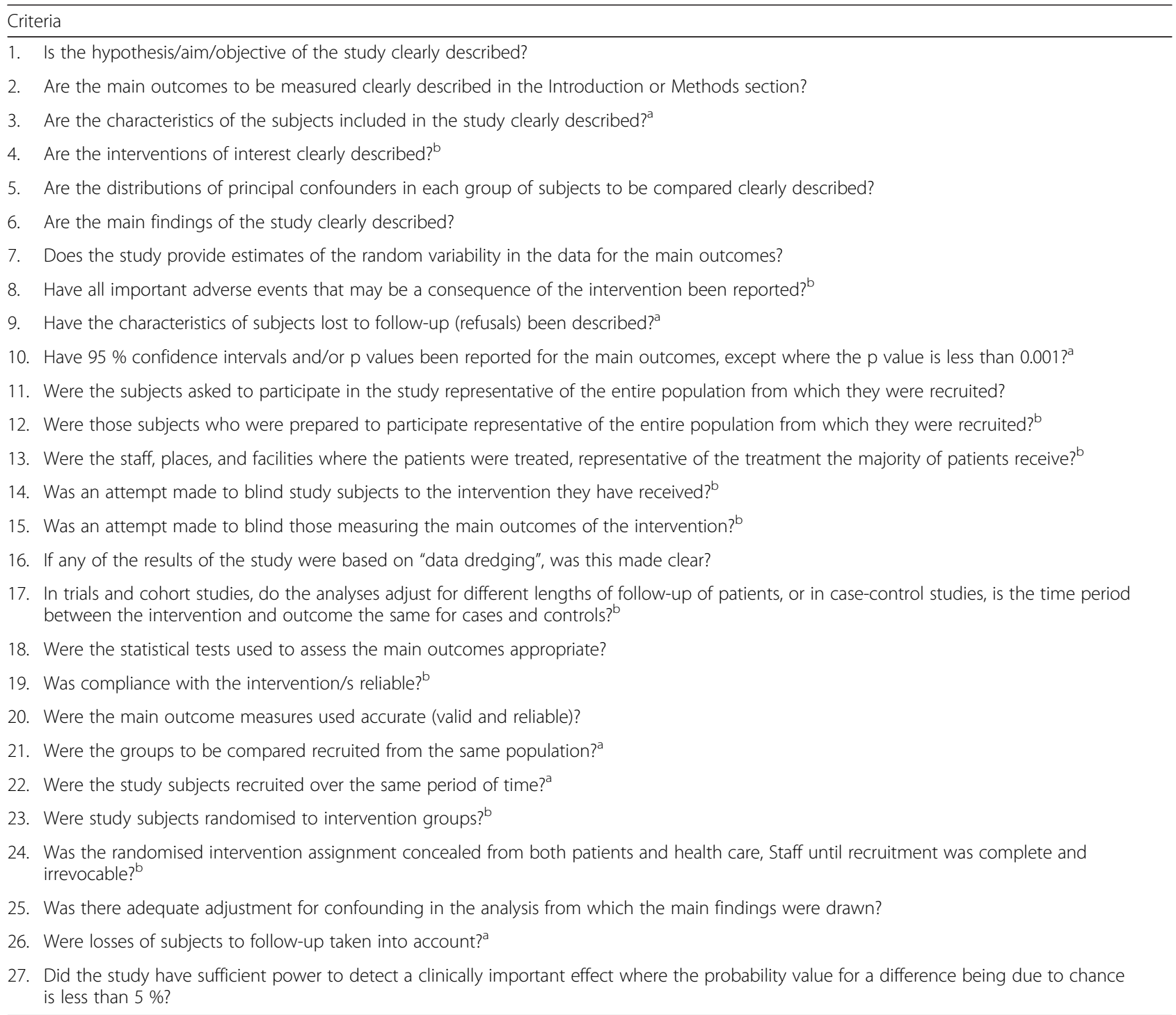

${ }^{a}$ Questions adapted for longitudinal studies

${ }^{b}$ Questions disregarded in this assessment as they did not apply to observational studies

fifth month of life [13]. Five studies assessed the effect of being breastfed (yes/no) irrespective of exclusivity or duration $[5-8,10]$. Five studies $[7-9,12,14]$ assessed the effect of longer duration of being breastfed (irrespective of exclusivity) on bone mass measurements. Only one study [9] assessed the effect of duration of EBF on BMC and BMD.

With regard to bone mass measurements, of the eleven studies, eight assessed BMC and BMD [6, 7, 9, 11-15], two assessed BMC only $[5,10]$ while one evaluated BMD only [8]. Regarding the anatomical sites studied, three studies assessed bone mass at three sites: whole body, lumbar spine and neck of the femur [5, 7, 14]; three studies assessed whole body only $[10,12,15]$; one investigated lumbar spine only
[13] whereas four studies assessed both whole body and lumbar spine $[6,8,9,11]$.

\section{Effect of being breastfed on bone mineral mass}

Among the studies assessing the association of interest in children, three did not find association [12, 13, 15]; two found higher bone mass values among children who were breastfed [5, 7], and one showed that breastfed children had lower whole body BMC compared with those fed with formula, as well as an inverse relationship between duration of total time breastfed and bone mass [10].

The bone mass assessment in adolescents also showed diverse findings. While two studies observed higher bone mass values among those who were breastfed [6, 8]; one 


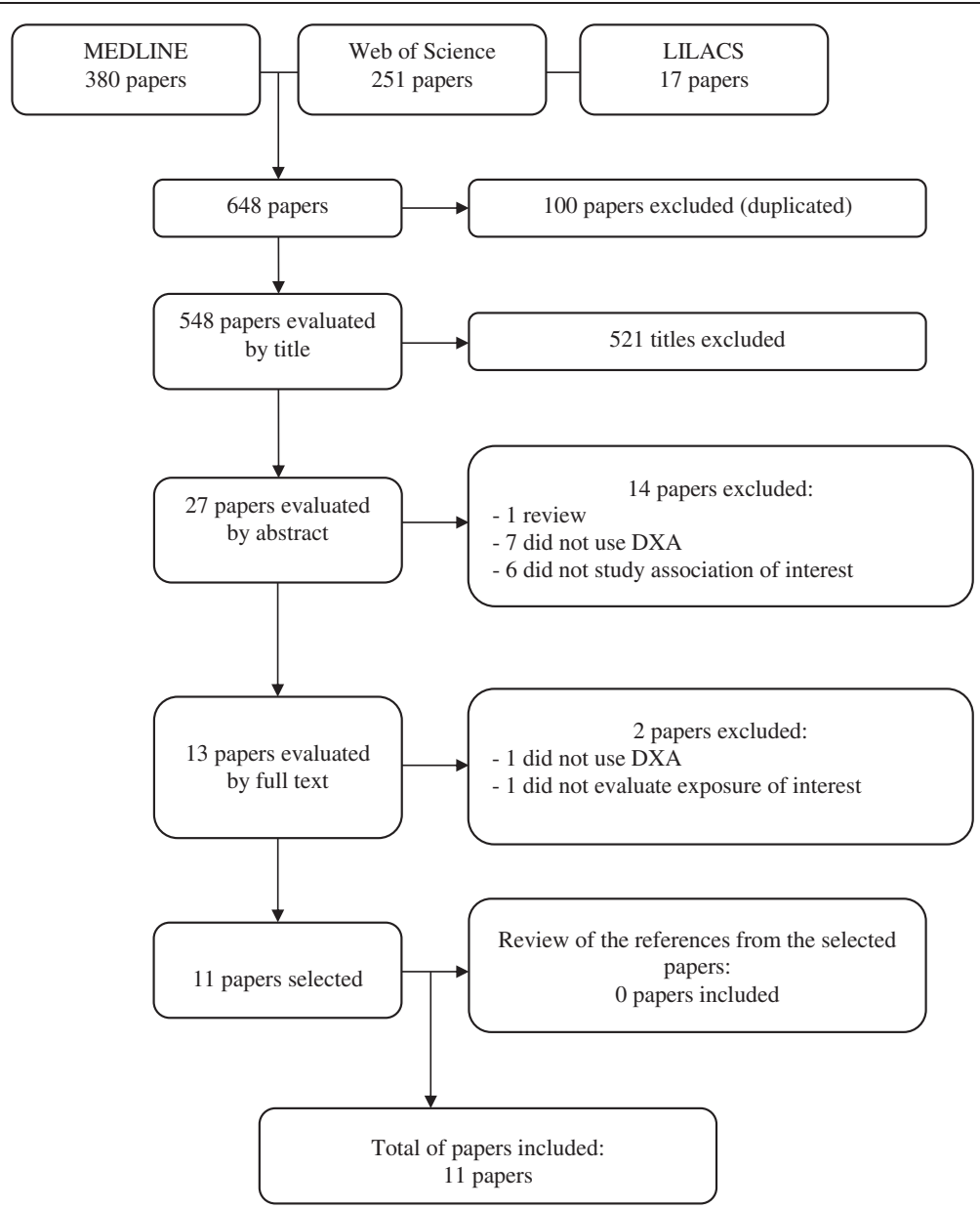

Fig. 1 Flow chart of articles assessing the association between method of infant feeding and bone mass measured by DXA at different ages

reported a direct relation between breastfeeding duration and bone outcomes [9] and one did not find any association [11].

The study evaluating adults found lower BMC and $\mathrm{BMO}$ values among men breastfed in infancy for long periods of time. In women, there was no effect of being breastfed on bone mass.

\section{Discussion}

The number of relevant articles found in the present review was small, due to the lack of studies assessing methods of infant feeding compared to bone mineral mass in later life. This low number might be because the present review only assessed the effect of being breastfed on bone mineral mass in individuals born at term with normal weight for gestational age. Studies conducted in preterm newborns were excluded ( $<37$ weeks' gestation), since this group potentially has suboptimal mineralization, given that bone mineral deposition is most intense and rapid during the third trimester of pregnancy [19]. Thus, it is likely that effects of breastfeeding on bone mineral mass, over the short and long-term, in preterm infants differs from those observed in term infants.

Although the literature has confirmed the influence of method of infant feeding on body composition in later life, the relationship between being breastfed and bone mineral mass is complex. In this review, the studies that found positive effects of being breastfed (regardless of exclusivity or duration) on BMC and/or BMD showed that formula-fed children had lower bone mass compared to those fed with breast milk [5-8]. Human milk contains lower levels of the nutrients essential for bone mineralization, such as calcium, phosphorus and vitamin D [7], compared to infant formulas and other types of milk. Notwithstanding, there are several explanations for the beneficial effect of breast milk, namely: (1) despite the lower concentration of calcium and phosphorus in human milk, the bioavailability and absorption of these nutrients is greater than other types of milk [7]; (2) consumption of breast milk results in the intake of $200 \mathrm{mg}$ of calcium per day on average [20-22], a sufficient amount to promote good skeletal development during 
Table 2 Synthesis of studies that evaluated association between method of infant feeding and bone mineral mass during childhood, adolescence or in adults

\begin{tabular}{|c|c|c|c|c|c|c|c|c|c|}
\hline $\begin{array}{l}\text { Author } \\
\text { Place/Year } \\
\text { Score }^{a}\end{array}$ & $\begin{array}{l}\text { Design } \\
\text { studies }\end{array}$ & $\mathrm{Age}^{\mathrm{b}}$ & Sex & $\mathrm{N}$ & Exposure & Outcome & Results & Analysis & Adjustment \\
\hline \multicolumn{10}{|c|}{ Papers evaluating children } \\
\hline $\begin{array}{l}\text { Park [13], } \\
\text { Korea 1998, } \\
10^{\mathrm{a}}\end{array}$ & $\begin{array}{l}\text { Cross- } \\
\text { sectional }\end{array}$ & $\begin{array}{l}2-5 \\
\text { months }\end{array}$ & $\begin{array}{l}22 \mathrm{M} \\
13 \mathrm{~F}\end{array}$ & $\begin{array}{l}35,18 \\
\mathrm{BF}, 17 \\
\mathrm{FF}\end{array}$ & $\begin{array}{l}\text { Exclusive BF (from birth to } \\
5 \text { months) }\end{array}$ & $\mathrm{BMC}$ and $\mathrm{BMD}$ spine & $\begin{array}{l}\text { No association between } \\
\text { breastfeeding and bone } \\
\text { mass }\end{array}$ & $\begin{array}{l}\text { Multiple } \\
\text { regression }\end{array}$ & Age and body weight \\
\hline $\begin{array}{l}\text { Butte [10], } \\
\text { US 2000, } 13^{\text {a }}\end{array}$ & Cohort & $\begin{array}{l}0.5,12 \\
\text { and } \\
24 \text { months }\end{array}$ & $\begin{array}{l}33 \mathrm{M} \\
43 \mathrm{~F}\end{array}$ & $\begin{array}{l}76,40 \\
B F, 36 \\
F F\end{array}$ & $\begin{array}{l}\text { Exclusive BF (from birth to } \\
4 \text { months) Duration of BF }\end{array}$ & BMC whole body & $\begin{array}{l}\text { Negative association } \\
\text { between breastfeeding } \\
\text { and bone mass }\end{array}$ & $\begin{array}{l}\text { Pearson } \\
\text { correlation and } \\
\text { linear regression }\end{array}$ & Current weight and length \\
\hline $\begin{array}{l}\text { Jones [7], } \\
\text { Australia } \\
2000,16^{\mathrm{a}}\end{array}$ & Cohort & 8 years & $\begin{array}{l}215 \mathrm{M} \\
115 \mathrm{~F}\end{array}$ & $\begin{array}{l}330 \\
175 \mathrm{BF} \\
151 \mathrm{FF}\end{array}$ & $\begin{array}{l}\text { BF (no, yes) Duration of BF } \\
\text { (not, less than } 3 \text { months, } \\
3 \text { months or larger) }\end{array}$ & $\begin{array}{l}\text { BMC and BMD } \\
\text { whole body, spine, } \\
\text { femoral neck }\end{array}$ & $\begin{array}{l}\text { Positive association } \\
\text { between breastfeeding } \\
\text { and bone mass }\end{array}$ & $\begin{array}{l}\text { Multiple linear } \\
\text { regression }\end{array}$ & $\begin{array}{l}\text { Sex, current weight and length, } \\
\text { age solids introduced, sports } \\
\text { participation, sunlight exposure } \\
\text { and current calcium intake }\end{array}$ \\
\hline $\begin{array}{l}\text { Young [15], } \\
\text { EUA 2005, } \\
10^{\mathrm{a}}\end{array}$ & Cohort & 4 years & $\begin{array}{l}103 \mathrm{M} \\
75 \mathrm{~F}\end{array}$ & $\begin{array}{l}178,57 \\
\mathrm{BF}, 121 \\
\mathrm{FF}\end{array}$ & $\begin{array}{l}\text { Exclusive BF (from birth } \\
\text { to } 4 \text { months) }\end{array}$ & $\begin{array}{l}\text { BMC and BMD } \\
\text { whole body }\end{array}$ & $\begin{array}{l}\text { No association between } \\
\text { breastfeeding and } \\
\text { bone mass }\end{array}$ & $\begin{array}{l}\text { Analysis of } \\
\text { variance }\end{array}$ & Crude \\
\hline $\begin{array}{l}\text { Harvey [12], } \\
\text { UK 2009, } 16^{\text {a }}\end{array}$ & Cohort & 4 years & $\begin{array}{l}318 \mathrm{M} \\
281 \mathrm{~F}\end{array}$ & 599 & $\begin{array}{l}\text { Duration of BF (never tried, } \\
<1 \text { month, 1-3 months, } \\
4-6 \text { months, } 7-11 \text { months, } \\
12 \text { months or more) }\end{array}$ & $\begin{array}{l}\text { BMC and BMD } \\
\text { whole body }\end{array}$ & $\begin{array}{l}\text { No association between } \\
\text { breastfeeding and } \\
\text { bone mass }\end{array}$ & $\begin{array}{l}\text { Correlation and } \\
\text { linear regression }\end{array}$ & $\begin{array}{l}\text { Bone area, weight, height, childhood } \\
\text { milk intake, maternal birth weight, } \\
\text { social class, mother's prudent diet } \\
\text { score, parity, physical activity, } \\
\text { body build (triceps skinfold } \\
\text { thickness) and smoking }\end{array}$ \\
\hline $\begin{array}{l}\text { Andres [5], } \\
\text { EUA 2013, } \\
15^{\mathrm{a}}\end{array}$ & Cohort & $\begin{array}{l}3,6,9 \text { and } \\
12 \text { months }\end{array}$ & $\begin{array}{l}130 \mathrm{M} \\
77 \mathrm{~F}\end{array}$ & 207 & BF (no, yes) & $\begin{array}{l}\text { BMC whole body, } \\
\text { spine, femoral neck }\end{array}$ & $\begin{array}{l}\text { Positive association } \\
\text { between breastfeeding } \\
\text { and bone mass }\end{array}$ & $\begin{array}{l}\text { Logistic } \\
\text { regression }\end{array}$ & $\begin{array}{l}\text { Age, sex, race, gestational age, } \\
\text { birth weight, birth length, food } \\
\text { history and socioeconomic } \\
\text { status of the mother }\end{array}$ \\
\hline \multicolumn{10}{|c|}{ Papers evaluating adolescents } \\
\hline $\begin{array}{l}\text { Foley [6] } \\
\text { Australia } \\
2009,15^{\mathrm{a}}\end{array}$ & Cohort & 16 years & $\begin{array}{l}116 \mathrm{M} \\
67 \mathrm{~F}\end{array}$ & 183 & $\begin{array}{l}\text { BF (no, yes) reported by } \\
\text { the mother approximately } \\
1 \text { month after birth }\end{array}$ & $\begin{array}{l}\text { BMC and } \mathrm{aBMD} \\
\text { whole body and } \\
\text { spine }\end{array}$ & $\begin{array}{l}\text { Positive association } \\
\text { between breastfeeding } \\
\text { and bone mass }\end{array}$ & $\begin{array}{l}\text { Logistic } \\
\text { regression }\end{array}$ & Age, weight and height \\
\hline $\begin{array}{l}\text { Molgaard [9], } \\
\text { Denmark } \\
2011,15^{\text {a }}\end{array}$ & Cohort & 17 years & $\begin{array}{l}\text { Males, } \\
\text { Females }\end{array}$ & 109 & $\begin{array}{l}\text { Duration of exclusive BF } \\
\text { and any BF up to } 9 \text { months. } \\
\text { If the infants were breastfed } \\
\text { at least once a day, they } \\
\text { were classified as breastfed }\end{array}$ & $\begin{array}{l}\mathrm{BMC} \text { and } \mathrm{BMD} \\
\text { whole body and } \\
\text { spine }\end{array}$ & $\begin{array}{l}\text { Positive association } \\
\text { between breastfeeding } \\
\text { and bone mass }\end{array}$ & Correlation & Sex, weight and height \\
\hline $\begin{array}{l}\text { Fewtrell [11], } \\
\text { UK 2013, } 16^{\mathrm{a}}\end{array}$ & $\begin{array}{l}\text { Randomised } \\
\text { trial }\end{array}$ & 10 years & $\begin{array}{l}193 \mathrm{M} \\
130 \mathrm{~F}\end{array}$ & $\begin{array}{l}323 \\
120 \mathrm{BF} \\
203 \mathrm{FF}\end{array}$ & $\begin{array}{l}\text { Exclusive BF (from birth } \\
\text { to } 12 \text { weeks) }\end{array}$ & $\begin{array}{l}\text { BMC and BMD } \\
\text { whole body and } \\
\text { spine }\end{array}$ & $\begin{array}{l}\text { No association between } \\
\text { breastfeeding and } \\
\text { bone mass }\end{array}$ & $\begin{array}{l}\text { Multiple } \\
\text { regression }\end{array}$ & $\begin{array}{l}\text { Sex, age, pubertal stage, weight, } \\
\text { height, current physical activity } \\
\text { and calcium intake }\end{array}$ \\
\hline $\begin{array}{l}\text { Jones [8] } \\
\text { Australia } \\
2013,16^{\mathrm{a}}\end{array}$ & Cohort & 16 years & $\begin{array}{l}150 \mathrm{M} \\
265 \mathrm{~F}\end{array}$ & 415 & $\begin{array}{l}\text { BF at } 1 \text { month (no, yes) } \\
\text { and BF at } 3 \text { months (no, } \\
\text { yes), Duration of BF }\end{array}$ & $\begin{array}{l}\text { BMD whole body } \\
\text { and spine }\end{array}$ & $\begin{array}{l}\text { Positive association } \\
\text { between breastfeeding } \\
\text { and bone mass }\end{array}$ & $\begin{array}{l}\text { Multivariable } \\
\text { linear regression }\end{array}$ & $\begin{array}{l}\text { Sex, age, current weight and } \\
\text { height }\end{array}$ \\
\hline
\end{tabular}


Table 2 Synthesis of studies that evaluated association between method of infant feeding and bone mineral mass during childhood, adolescence or in adults (Continued)

(never, $<25$ days and

$\geq 25$ days)

Papers evaluating adults

\begin{tabular}{|c|c|c|c|c|c|c|c|c|c|}
\hline $\begin{array}{l}\text { Pirilä [14], } \\
\text { Finland 2011, } \\
15^{\mathrm{a}}\end{array}$ & Cohort & 32 years & $\begin{array}{l}76 \mathrm{M} \\
82 \mathrm{~F}\end{array}$ & 158 & $\begin{array}{l}\text { Duration BF from birth } \\
\text { to } 12 \text { months (short } \\
\mathrm{BF} \leq 3 \text { months; } \\
\text { intermediate } \mathrm{BF} \\
>3 \text { but }<7 \text { months } \\
\text { and prolonged } \mathrm{BF} \\
\geq 7 \text { months) }\end{array}$ & $\begin{array}{l}\text { BMC and BMD } \\
\text { whole body, spine } \\
\text { and femoral neck }\end{array}$ & $\begin{array}{l}\text { Negative association } \\
\text { between breastfeeding } \\
\text { and bone mass only in } \\
\text { men, No association } \\
\text { between breastfeeding } \\
\text { and bone mass in women }\end{array}$ & $\begin{array}{l}\text { Multivariate } \\
\text { analysis of } \\
\text { covariance }\end{array}$ & $\begin{array}{l}\text { Gender, dietary intake of calcium, } \\
\text { teen-age and current physical activity, } \\
\text { smoking history, alcohol consumption, } \\
\text { pregnancies, fractures, weight, height, } \\
\text { BMl, weight changes during adult life } \\
\text { and birth weight }\end{array}$ \\
\hline
\end{tabular}

$(n=11)$

${ }^{a}$ Score by Downs \& Black. ${ }^{b}$ Age outcome. $M$ males, $F$ females, $B F$ breastfeeding, $F F$ formula feeding, $a B M D$ areal bone mineral density $\left(\mathrm{g} / \mathrm{cm}^{2}\right)$ 
infancy, which can persist into later life; and also, (3) the potentiating effect of breast milk on bone development may stem from a non-nutritional factor [19]. Furthermore, early exposure to breast milk, albeit for a brief period, can lead to changes in the programming of bone cells, resulting in greater bone mass in later life [23].

With respect to breastfeeding duration, Jones et al. showed that children breastfed for longer ( $\geq 3$ months) had higher bone mass values at eight months of life [7]. Molgaard et al. also observed a direct relationship between duration of being breastfed and bone mass in young adults aged 17 years [9]. By contrast, Pirila et al. found that males breastfed for less than three months had higher BMC and BMD at 32 years of age than males breastfed for longer periods (greater than seven months) [14]. One explanation for this finding is that in the first six months of life, the level of calcium present in breast milk is relatively constant, falling by $20-30 \%$ when lactation continues beyond the sixth month [24]. From the sixth month, if the child does not have a nutritionally sufficient and adequate supplementary diet, the calcium level in breast milk may be insufficient to promote normal growth and bone development. In addition, intestinal absorption and urinary excretion of calcium may be positively or negatively affected by other types of milk consumed, impairing the bone mineralization process [25].

It is noteworthy that although all the studies included in this review were conducted in high-income countries, inconsistent associations were found; possibly, due to different contexts regarding breastfeeding between these countries. Studies observing a positive association between being breastfed and bone mass were conducted in countries where the practice of breastfeeding is known to be more commonplace, such as Denmark and Australia [6,9]. Conversely, in countries where breastfeeding is less widely practiced and promoted, a negative or absence of association was observed $[10,12,15]$.

A notable limiting factor of this review was the lack of homogeneity in the approach adopted for assessing breastfeeding among the selected studies. This aspect precluded the determination of an overall measurement of the effect of being breastfed on bone mass from a meta-analysis. Another relevant limitation was that the studies controlled for different confounding factors which, to some degree, hampered comparison of the findings. A negative yet important aspect concerns the low number of studies providing data stratified by gender. Boys and girls are known to reach peak bone mass at different ages, with differences most marked during the prepubertal stage $[1,26,27]$.

However, it is important to point out that this review was performed systematically by two authors independently using a broad set of key-words and no limitations on publication date. Of the studies included, most were longitudinal in design, strengthening the causality relationship of the associations found [1, 27]. In addition, the review included studies assessing bone mass using DXA, considered the gold standard for measuring BMC/ BMD by the International Society for Clinical Densitometry [28]. This inclusion of studies that only employed DXA for assessing bone mass ensured high validity and comparability of the BMC/BMD measurements collected by the studies. Also, the methodological assessment of the articles included in this review suggested they are of sufficient quality, i.e. have high internal validity.

\section{Conclusions}

In conclusion, the results of the present review were conflicting across the different age groups. Analysis of the results stratified by age group revealed a lack of consensus among the studies assessing outcome in infancy; evidence of a positive effect of being breastfed on bone mass measurements in adolescence; and a failure to reach a conclusion regarding the effect in adulthood, given that only one such study was included in the review and that effects were observed only among men. Taken together, these results suggest that being breastfed exerts a greater effect in the long-term, particularly in adolescence, a phase during which around $90 \%$ of peak bone mass is attained [29]. In view of the small number of studies supporting these conclusions, further studies are needed, particularly among low-middle income countries. This information is fundamental, not only to inform policies on feeding and nutrition during infancy and adolescence, but also for policies for reducing chronic diseases in adulthood.

\section{Abbreviations}

BMC: bone mineral content; BMD: bone mineral density; DXA: Dual-energy x-ray absorptiometry; EBF: exclusive breastfeeding; LILACS: Literatura

Latino-Americana e do Caribe em Ciências da Saúde; WoS: web of science.

\section{Competing interests}

The authors declare that they have no competing interests.

\section{Authors' contributions}

LCM and RB were responsible for the systematic review, data compilation and drafted the manuscript. FCW, AMBM and MCFA guided every step and critically reviewed the manuscript. All authors read and approved the final manuscript.

Received: 8 November 2014 Accepted: 14 November 2015 Published online: 20 November 2015

\section{References}

1. Cooper C, Westlake S, Harvey N, Javaid K, Dennison E, Hanson M. Review: developmental origins of osteoporotic fracture. Osteoporos Int. 2006:17(3):337-47.

2. Cooper C, Cawley M, Bhalla A, Egger P, Ring F, Morton L, et al. Childhood growth, physical activity and peak bone mass in women. J Bone Miner Res. 1995;10:940-7.

3. Cooper C, Fall C, Egger P, Hobbs R, Eastell R, Barker D. Growth in infancy and bone mass in later life. Ann Rheum Dis. 1997:56:17-21. 
4. Kuh D, Ben-Shlomo Y. A life course approach to chronic disease epidemiology. New York: Oxford University Press; 2004.

5. Andres A, Casey PH, Cleves MA, Badger TM. Body fat and bone mineral content of infants fed breast milk, cow's milk formula, or soy formula during the first year of life. J Pediatr. 2013;163(1):49-54.

6. Foley $\mathrm{S}$, Quinn $\mathrm{S}$, Jones $\mathrm{G}$. Tracking of bone mass from childhood to adolescence and factors that predict deviation from tracking. Bone. 2009;44(5):752-7.

7. Jones G, Riley M, Dwyer T. Breastfeeding in early life and bone mass in prepubertal children: a longitudinal study. Osteoporos Int. 2000;11(2):146-52.

8. Jones G, Hynes KL, Dwyer T. The association between breastfeeding, maternal smoking in utero, and birth weight with bone mass and fractures in adolescents: a 16-year longitudinal study. Osteoporos Int. 2013;24:1605-11.

9. Molgaard C, Larnkjaer A, Mark AB, Michaelsen KF. Are early growth and nutrition related to bone health in adolescence? The Copenhagen Cohort Study of infant nutrition and growth. Am J Clin Nutr. 2011;94 Suppl 6:1865S-9S.

10. Butte NF, Wong WW, Hopkinson JM, O'Brian Smith E, Ellis KJ. Infant feeding mode affects early growth and body composition. Pediatrics. 2000;106(6):1355-66

11. Fewtrell MS, Kennedy K, Murgatroyd PR, Williams JE, Chomtho S, Lucas A. Breast-feeding and formula feeding in healthy term infants and bone health at age 10 years. Br J Nutr. 2013;110(6):1-7.

12. Harvey NC, Robinson SM, Crozier SR, Marriott LD, Gale CR, Cole ZA, et al. Breast-feeding and adherence to infant feeding guidelines do not influence bone mass at age 4 years. Br J Nutr. 2009;102(6):915-20.

13. Park MJ, Namgung R, Kim DH, Tsang RC. Bone mineral content is not reduced despite low vitamin $D$ status in breast milk-fed infants versus cow's milk based formula-fed infants. J Pediatr. 1998;132(4):641-5.

14. Pirila S, Taskinen M, Viljakainen H, Kajosaari M, Turanlahti M, Saarinen-Pihkala UM, et al. Infant milk feeding influences adult bone health: a prospective study from birth to 32 years. PLoS One. 2011;6(4):e19068.

15. Young RJ, Antonson DL, Ferguson PW, Murray ND, Merkel K, Moore TE. Neonatal and infant feeding: Effect on bone density at 4 years. J Pediatr Gastroenterol Nutr. 2005;41(1):88-93.

16. Ravelli AC, van der Meulen JH, Osmond C, Barker DJ, Bleker OP. Infant feeding and adult glucose tolerance, lipid profile, blood pressure, and obesity. Arch Dis Child. 2000;82(3):248-52.

17. World Health Organization. WHO Scientific Group on the Assessment of Osteoporosis at Primary Health Care Level. In: WHO Scientific Group on the Assessment of Osteoporosis at Primary Health Care Level. Geneva: World Health Organization; 2007.

18. Downs SH, Black N. The feasibility of creating a checklist for the assessment of the methodological quality both of randomised and non-randomised studies of health care interventions. J Epidemiol Community Health. 1998;52:377-84.

19. Fewtrell M. Early nutritional predictors of long-term bone health in preterm infants. Curr Opin Clin Nutr Metab Care. 2011;14(3):297-301.

20. Ong KK, Preece MA, Emmett PM, Ahmed ML, Dunger DB, ALSPAC Study Team. Size at birth and early childhood growth in relation to maternal smoking, parity and infant breast-feeding: Longitudinal birth cohort study and analysis. Pediatr Res. 2002;52(6):863-7.

21. Prentice A. Micronutrients and the bone mineral content of the mother, fetus and newborn. J Nutr. 2003;133(5 Suppl 2):1693S-9S.

22. Bates CJ, Prentice A. Breast milk as a source of vitamins, essential minerals and trace elements. Pharmacol Ther. 1994;62:193-220.

23. Morley R, Lucas A. Influence of early diet on outcome in preterm infants. Acta Paediatr. 1994;405:123-6.

24. Prentice A, Jarjou LM, Cole TJ, Stirling DM, Dibba B, Fairweather-Tait S Calcium requirements of lactating Gambian mothers: Effects of a calcium supplement on breast-milk calcium concentration, maternal bone mineral content, and urinary calcium excretion. Am J Clin Nutr. 1995;62:58-67.

25. Prentice A. Diet, nutrition and osteoporosis. Public Health Nutr. 2004;7:237-54.

26. Baroncelli Gl, Saggese G. Critical ages and stages of puberty in the accumulation of spinal and femoral bone mass: the validity of bone mass measurements. Horm Res. 2000;54 Suppl 1:2-8.

27. Grimes DA, Schulz KF. Cohort studies: marching towards outcomes. Lancet 2002;359(9303):341-5.

28. Lewiecki EM, Watts NB, McClung MR, Petak SM, Bachrach LK, Shepherd JA, et al. Official positions of the international society for clinical densitometry. J Clin Endocrinol Metab. 2004;89(8):3651-5.

29. Heaney RP, Abrams S, Dawson-Hughes B, Looker A, Marcus R, Matkovic V, et al. Peak bone mass. Osteoporos Int. 2000;11(12):985-1009.

Submit your next manuscript to BioMed Central
and we will help you at every step:
- We accept pre-submission inquiries
- Our selector tool helps you to find the most relevant journal
- We provide round the clock customer support
- Convenient online submission
- Thorough peer review
- Inclusion in PubMed and all major indexing services
- Maximum visibility for your research
Submit your manuscript at
www.biomedcentral.com/submit

